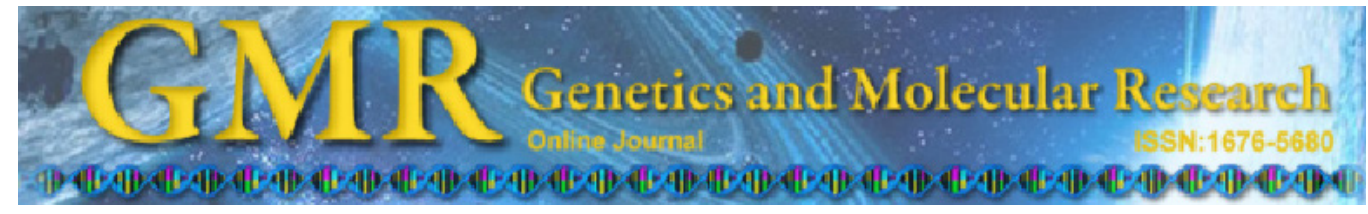

\title{
The epimer of kaurenoic acid from \\ Croton antisyphiliticus is cytotoxic toward B-16 and HeLa tumor cells through apoptosis induction
}

\author{
V.C. Fernandes, S.I.V. Pereira, J. Coppede, J.S. Martins, W.F. Rizo, \\ R.O. Beleboni, M. Marins, P.S. Pereira, A.M.S. Pereira and A.L. Fachin \\ Unidade de Biotecnologia, Universidade de Ribeirão Preto, Ribeirão Preto, \\ SP, Brasil \\ Corresponding author: A.L. Fachin \\ E-mail: afachin@unaerp.br
}

Genet. Mol. Res. 12 (2): 1005-1011 (2013)

Received June 18, 2012

Accepted January 5, 2013

Published April 2, 2013

DOI http://dx.doi.org/10.4238/2013.April.2.16

\begin{abstract}
Cancer has become the leading cause of death in developing countries due to increased life expectancy of the population and changes in lifestyle. Studies on active principles of plant have motivated researchers to develop new antitumor agents that are specific and effective for treatment of neoplasms. Kaurane diterpenes are considered important compounds in the development of new and highly effective anticancer chemotherapeutic agents due to their cytotoxic properties in the induction of apoptosis. We evaluated the cytotoxic and apoptotic activity of the epimer of kaurenoic acid (EKA) isolated from the medicinal plant Croton antisyphiliticus (Euphorbiaceae) toward tumor cell lines HeLa and B-16 and normal fibroblasts 3T3. Based on analyses with the MTT test, EKA showed cytotoxic activity, with half maximal inhibitory concentration values of 59.41, 68.18 and $60.30 \mu \mathrm{g} /$ $\mathrm{mL}$ for the B-16, HeLa and $3 \mathrm{~T} 3$ cell lines, respectively. The assay for necrotic or apoptotic cells by differential staining showed induction of apoptosis in all three cell lines. We conclude that EKA is not selective
\end{abstract}


between tumor and normal cell lines; the mechanism of action of EKA is induction of apoptosis, which is part of the innate mechanism of cell defense against neoplasia.

Key words: Apoptosis; B-16; Diterpene; HeLa; MTT

\section{INTRODUCTION}

According to the World Health Organization, cancer is the leading cause of death worldwide (WHO, 2008). Its impact on world public health was projected to increase from 12.4 million new cases and 7.6 million deaths in 2008 to 26.4 million new cancer cases and 17 million deaths in 2030. The low- and middle-income countries account for $70 \%$ of all cancer deaths, which are mainly caused by tobacco use, alcohol use, unhealthy diet, and physical inactivity (Jemal et al., 2011). Among the many different types, lung cancer is the leading cause of cancer deaths worldwide (1.37 million deaths), followed by stomach (736,000 deaths), liver (695,000 deaths), colorectal (608,000 deaths), breast (458,000 deaths), and cervical (275,000 deaths) cancer (Ferlay et al., 2010). Among these, cervical cancer is the second most commonly diagnosed cancer in women worldwide and is an important public health problem among adult women in developing countries, which account for $85 \%$ of the 533,000 worldwide cases (Ferlay et al., 2010; Arbyn et al., 2011). Lately, however, other types of cancer have emerged as new burdens for public heath, such as melanoma, which is now one of the most common forms of cancer. According to the USA and Canadian cancer societies, over 75,000 North Americans were expected to be diagnosed with melanoma and over 9000 were expected to die from it in the year 2011. The poor response of metastatic melanoma to most systemic therapies and its 5 -year survival rate ranging from 5 to $10 \%$ reinforce its importance as a health care issue (Balch et al., 2001).

Although there have been successful uses of many chemotherapeutic agents in the treatment of several kinds of cancer, the development of drug resistance by cancer cells has limited their application in systemic or local treatment (Szakacs et al., 2006). This has become a challenge that has prompted the search for new types of compounds with suitable pharmacological properties to overcome the different resistance mechanisms involving decreased uptake of water-soluble drugs, changes in cell metabolism that affect the capacity of cytotoxic drugs, and increased energy-dependent efflux of hydrophobic drugs that easily enter the cells by diffusion through the plasma membrane (Roberti et al., 2006; Szakacs et al., 2006).

Natural products are a rich source of new drugs, and numerous substances with cytotoxic activity have been isolated from natural products of plant origin (Gordaliza, 2007; Newman and Cragg, 2012). An important class includes the diterpenes, which have been recognized for a wide range of pharmacological properties such as antiinflammatory, antiulcer, antiviral, cytotoxic, antimicrobial, gastroprotective, and analgesic activities (Navarro et al., 2000; Januario et al., 2004; Paula de Oliveira et al., 2011; Premprasert et al., 2012; Vidal et al., 2012). A classic example is Taxol (paclitaxel), a plant-derived tubulin-binding diterpene that inhibits cell proliferation and induces cell apoptosis (Rowinsky, 1997). It has been approved for use in the treatment of AIDS-related Kaposi sarcoma, breast cancer, non-small cell lung cancer, and ovarian cancer. Moreover, the drug also shows activity against cancers of the esophagus, bladder, and head and neck (Mekhail and Markman, 2002; Sun et al., 2009). 
Phytochemical investigations on the genus Croton (family Euphorbiaceae) have shown that these plants produce diterpenoids of various skeletal types such as cembranoids, clerodane, neoclerodane, halimane, isopimarane, kaurane, secokaurane, labdane, phorbol, and trachylobane (Salatino et al., 2007). Kaurane diterpenes are considered important compounds in the development of new effective cancer chemotherapeutic agents due to their cytotoxic property (Cavalcanti et al., 2009) being related to the induction of apoptosis via inhibition of NF- $\mathrm{kB}$ and activation of caspase 8 (Mongelli et al., 2002). The clonal expansion of transformed cells depends on a lack of proliferative capacity and decreased cell death by apoptosis. Most malignant tumors are characterized by resistance to apoptosis, and as a result, apoptosis becomes a potential target for both therapeutic use of programmed cell death and for understanding the mechanisms of resistance to radiotherapy and chemotherapy (Olsson and Zhivotovsky, 2011).

The present study investigated the cytotoxic activity of the diterpene epimer of kaurenoic acid (EKA) isolated from Croton antisyphiliticus against cell lines of human cervical carcinoma (HeLa), murine melanoma (B-16) and normal mouse embryo fibroblasts (3T3) using the MTT assay. In addition, we evaluated apoptosis induction in these cell lines as a mechanism of drug action.

\section{MATERIAL AND METHODS}

\section{Chemical agents}

Fetal bovine serum was purchased from Cutilab (Campinas, São Paulo, Brazil). Penicillin, streptomycin, doxorubicin, Dulbecco's modified Eagle's and HAM-F10 medium, DMSO, isopropanol, MTT, actinomycin D, acridine orange, ethidium bromide, and trypsin were obtained from Sigma Chemicals (St. Louis, MO, USA).

The diterpene EKA (Figure 1) was isolated from the chloroform extract of C. antisyphiliticus roots and kindly provided by Prof. Ana Maria Soares Pereira (Biotechnology Unit, UNAERP). The purity of EKA and its chemical identity were checked by NMR and mass spectrometry techniques (data not shown).

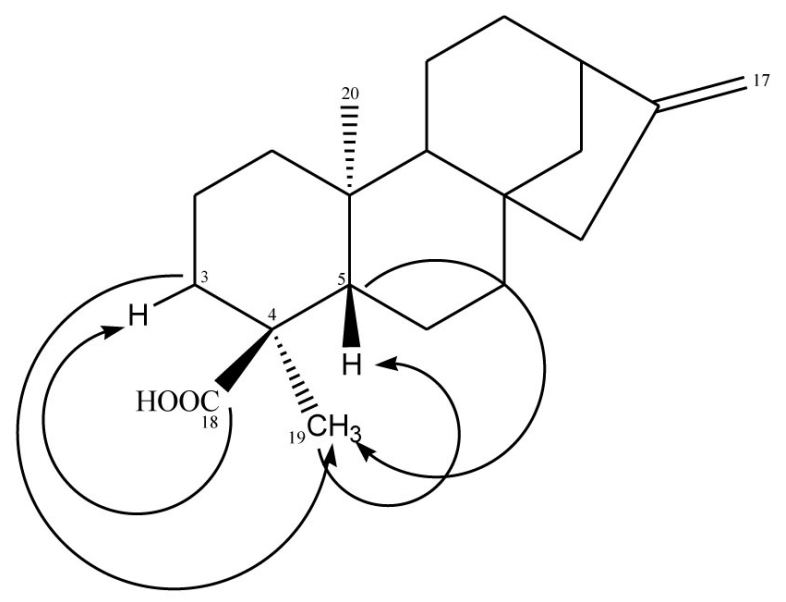

Figure 1. Chemical structure of EKA (epimer of kaurenoic acid: ent-kaur-16-en-18-oic acid). 


\section{Cytotoxicity testing}

Cells were incubated at $37^{\circ} \mathrm{C}$ in a humidified atmosphere containing $5 \% \mathrm{CO}_{2} .3 \mathrm{~T} 3$ (normal mouse embryo fibroblasts) and HeLa (human cervical carcinoma) cell lines were grown in Dulbecco's modified Eagle's medium (Sigma), while B-16 cells (murine melanoma) were grown in HAM-F10 medium, both media supplemented with $10 \%$ fetal bovine serum and $100 \mathrm{U} / \mathrm{mL}$ penicillin and $100 \mu \mathrm{g} / \mathrm{mL}$ streptomycin to prevent bacterial growth. A stock solution $(50 \mathrm{mg} / \mathrm{mL})$ of EKA was prepared in $10 \%$ DMSO. EKA was directly diluted in the medium to obtain concentrations ranging from 0.8 to $100 \mu \mathrm{g} / \mathrm{mL}$. The final concentration of DMSO was less than $0.2 \%$ to avoid solvent toxicity and had no negative effects on the cell lines. Doxorubicin $(4 \mu \mathrm{g} / \mathrm{mL})$ was used as the positive control. Cells were trypsinized $(0.15 \%$ trypsin), counted in a hemocytometer and incubated on a 96-well plate (5 x $10^{3}$ cells/well) for $24 \mathrm{~h}$. After the addition of the diterpene or vehicle dissolved in fresh medium, the cells were incubated at $37^{\circ} \mathrm{C}$ in a $5 \% \mathrm{CO}_{2}$ atmosphere for $72 \mathrm{~h}$ and cytotoxicity was determined by the MTT assay (Mosmann, 1983). Accordingly, MTT $(5 \mathrm{mg} / \mathrm{mL}$ in Hanks solution, 20 $\mu \mathrm{L} /$ well) was added to the 96-well plate, and the cells were incubated for $4 \mathrm{~h}$ under the same conditions. All cell treatments were carried out in triplicate. The formazan dye formed was extracted with $200 \mu \mathrm{L}$ DMSO incubated for $1 \mathrm{~h}$ under the same conditions and quantified spectrophotometrically at $550 \mathrm{~nm}$ in a Thermo Plate reader. The absorbance of untreated cells was used as a reference.

\section{Detection of apoptosis}

Apoptosis was analyzed as described by Ribble et al. (2005). Briefly, $5 \times 10^{3}$ cells of the 3T3, HeLa and B-16 cell lines were grown in $25-\mathrm{cm}^{2}$ flasks for $24 \mathrm{~h}$ as described above. Fresh medium with $100 \mu \mathrm{g} / \mathrm{mL}$ EKA was added, and cells were incubated for $72 \mathrm{~h}$. Afterwards, cells were harvested by trypsinization, and centrifuged at $2500 \mathrm{rpm}(129 \mathrm{~g})$ for $5 \mathrm{~min}$. Doxorubicin was used as the positive control $(4 \mu \mathrm{g} / \mathrm{mL})$. All cell treatments were carried out in triplicate. The cells were resuspended in $150 \mu \mathrm{L}$ acridine orange and ethidium bromide $(100 \mu \mathrm{g} / \mathrm{mL}$ each), and a $20-\mu \mathrm{L}$ aliquot of cell suspension was examined under a fluorescence microscope. The number of viable, apoptotic and necrotic cells was determined for 300 cells per treatment.

\section{Data analysis}

The cytotoxicity results were analyzed by ANOVA (two-paired samples for average) at a level of significance of $\mathrm{P}<0.05$. $\mathrm{IC}_{50}$ values were calculated by nonlinear regression analysis. The results of apoptosis are reported as means \pm standard deviation and were analyzed by one-way ANOVA, followed by the Tukey test.

\section{RESULTS AND DISCUSSION}

The MTT assay was used to evaluate the cytotoxicity of EKA isolated from C. antisyphiliticus against different mammalian cell lines (Table 1). The diterpene showed moderate cytotoxic activity toward the cell lines HeLa and B-16, with $\mathrm{IC}_{50}$ values of 68.18 and $59.41 \mu \mathrm{g} /$ 
$\mathrm{mL}$, respectively. Doxorubicin showed an $\mathrm{IC}_{50}$ of $2.0-3.23 \mu \mathrm{g} / \mathrm{mL}$ against the tumor cell lines and normal fibroblasts. The EKA also exhibited cytotoxic activity against the normal $3 \mathrm{~T} 3$ cell line $\left(\mathrm{IC}_{50}=60.30 \mu \mathrm{g} / \mathrm{mL}\right)$, demonstrating that this diterpene was not specific for tumor cells. This fact is commonly reported for current chemotherapeutic agents, as also observed for doxorubicin in our tests. The most commonly used drugs are those that simply kill tumor cells, but they also end up damaging or killing neighboring healthy cells (Mancebo et al., 2002). The anticancer drugs available on the market today are not target specific and have many side effects, besides complications in the clinical treatment of cancer of various cell types (Patel and Goyal, 2012). The nonspecificity of antitumor drugs causes an undesirable number of specific and nonspecific effects. Some of the nonspecific effects are nausea and vomiting, renal failure, diarrhea, and alopecia, among others. Renal, liver, lung, and digestive toxicity are among the nonspecific effects (Mardini and Record, 2005), besides the cardiac toxicity of anthracyclines, that is, the class of doxorubicin (Barry et al., 2007). These factors have driven the urgent development of new effective and less toxic therapeutic approaches. Thus, the discovery of drugs from medicinal plants may play an important role in cancer treatment.

\begin{tabular}{lcc} 
Table 1. $\mathrm{IC}_{50}$ values $(\mu \mathrm{g} / \mathrm{mL})$ of kaurane diterpene isolated from Croton antisyphiliticus. & \\
\hline Cell line & Kaurane diterpene & Doxorubicin \\
\hline HeLa & 68.18 & 2.00 \\
B-16 & 59.41 & 2.02 \\
3T3 & 60.30 & 3.23 \\
\hline
\end{tabular}

Kaurane diterpenes are considered important compounds in the development of new highly effective anticancer chemotherapeutic agents (Cavalcanti et al., 2010). Kaurene diterpenes such as EKA have been considered important for the development of new effective anticancer compounds due to their cytotoxic property related to induction of apoptosis via inhibition of NF- $\mathrm{kB}$ and activation of caspase 8 (Mongelli et al., 2002). According to our results, EKA induced apoptosis in 3T3, HeLa and B-16 at a high concentration of $100 \mu \mathrm{g} /$ $\mathrm{mL}$, while doxorubicin induced necrosis more frequently than apoptosis in all cell lines at a concentration of $4 \mu \mathrm{g} / \mathrm{mL}$ (Figure 2). One of the most important advances in cancer research is the recognition that apoptosis is an important phenomenon in chemotherapy. An effective anticancer drug must kill or disable tumor cells without causing excessive damage to normal cells. This ideal situation occurs with drugs that selectively induce apoptosis in tumor cells. Apoptosis is part of the innate mechanism of cell defense against neoplasia and several cancer chemotherapeutic agents act by inducing apoptosis. This is a driving force behind the intense investigation of the molecular mechanisms of apoptosis, which has become a strategic target in cancer treatment (Kim et al., 2002; Grivicich et al., 2007). Cavalcanti et al. (2009) evaluated the activity of kauran-19-oic acid in a number of lymphocytic tumor cell lines treated for $72 \mathrm{~h}$. The kaurane compound showed moderate cytotoxic activity against all strains tested compared with doxorubicin and did not show selective activity against tumor cell lines. Moreover, the apoptosis and necrosis assays with HL-60 leukemic cells showed that the kaurane compound, after $4 \mathrm{~h}$ of treatment, induced an increase in the number of apoptotic cells in a dose-dependent manner. 


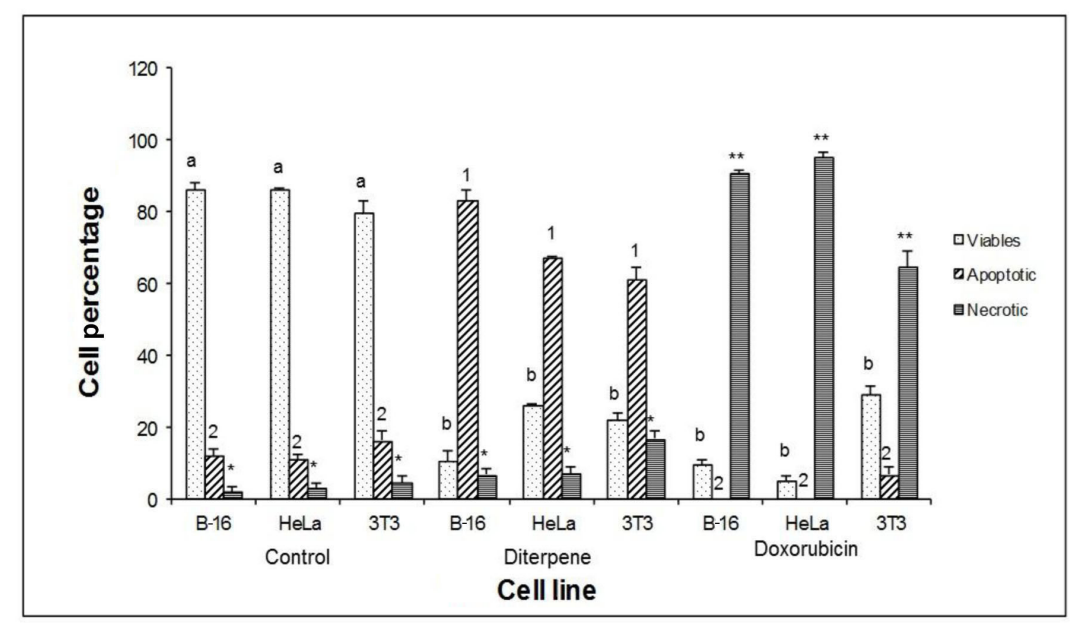

Figure 2. Percentage of viable $(\mathrm{a}, \mathrm{b})$, apoptotic $(1,2)$ and necrotic $(*, * *)$ cells grown in the presence of $100 \mu \mathrm{g} /$ $\mathrm{mL}$ EKA for $72 \mathrm{~h}$ in comparison to controls. $\mathrm{P}<0.01$ for different letters, numbers and asterisks (Scoot-Knott test).

Hueso-Falcón et al. (2010) evaluated 31 derivatives of kaurenoic acid, also at high concentration, for their cytotoxicity against the tumor cell lines HeLa, HepG2 and HT-29. Three compounds induced apoptosis by activation of caspase- 8 , while one induced apoptosis via induction of caspase-9. These results suggested that these kaurenoic acid derivatives act on tumor cells through induction of apoptosis. Thus, the results of the present study are in agreement with the literature, since it was shown that the diterpene studied, a kaurenoic acid derivative, induced apoptosis in 67 to $83.22 \%$ of HeLa, B-16 and 3T3 cells.

In conclusion, this is the first report of an epimer of kaurenoic acid isolated from $C$. antisyphiliticus, exhibiting moderate cytotoxic activity against a cervical cancer and melanoma cell line but also advantages in terms of its mechanism of action by inducing apoptosis in tumor cells. Furthermore, it should be emphasized that even if a plant-derived molecule cannot be directly used as a medicinal product, it can serve as a template for the synthesis or generation for the development of new anticancer agents (Brandão et al., 2010).

\section{ACKNOWLEDGMENTS}

Research supported by Biotechnology Unit, UNAERP.

\section{REFERENCES}

Arbyn M, Castellsagué X, de Sanjosé S, Bruni L, et al. (2011). Worldwide burden of cervical cancer in 2008. Ann. Oncol. 22: 2675-2686.

Balch CM, Buzaid AC, Soong SJ, Atkins MB, et al. (2001). Final version of the American Joint Committee on Cancer staging system for cutaneous melanoma. J. Clin. Oncol. 19: 3635-3648.

Barry E, Alvarez JA, Scully RE, Miller TL, et al. (2007). Anthracycline-induced cardiotoxicity: course, pathophysiology, prevention and management. Expert. Opin. Pharmacother. 8: 1039-1058.

Brandão HN, David JP, Couto RD, Nascimento JAP, et al. (2010). Chemistry and pharmacology of antineoplasic chemoterapeutical derivatives from plants. Quím. Nova 33: 1359-1369. 
Cavalcanti BC, Bezerra DP, Magalhaes HI, Moraes MO, et al. (2009). Kauren-19-oic acid induces DNA damage followed by apoptosis in human leukemia cells. J. Appl. Toxicol. 29: 560-568.

Cavalcanti BC, Ferreira JR, Moura DJ, Rosa RM, et al. (2010). Structure-mutagenicity relationship of kaurenoic acid from Xylopia sericeae (Annonaceae). Mutat. Res. 701: 153-163.

Ferlay J, Shin HR, Bray F, Forman D, et al. (2010). Estimates of worldwide burden of cancer in 2008: GLOBOCAN 2008. Int. J. Cancer 127: 2893-2917.

Gordaliza M (2007). Natural products as leads to anticancer drugs. Clin. Transl. Oncol. 9: 767-776.

Grivicich I, Regner A and Rocha AB (2007). Morte celular por apoptose. Rev. Bras. Cancerol. 53: 335-343.

Hueso-Falcón I, Girón N, Velasco P, Amaro-Luis JM, et al. (2010). Synthesis and induction of apoptosis signaling pathway of ent-kaurane derivatives. Bioorg. Med. Chem. 18: 1724-1735.

Januario AH, Santos SL, Marcussi S, Mazzi MV, et al. (2004). Neo-clerodane diterpenoid, a new metalloprotease snake venom inhibitor from Baccharis trimera (Asteraceae): anti-proteolytic and anti-hemorrhagic properties. Chem. Biol. Interact. 150: 243-251.

Jemal A, Bray F, Center MM, Ferlay J, et al. (2011). Global cancer statistics. CA Cancer J. Clin. 61: 69-90.

Kim R, Tanabe K, Uchida Y, Emi M, et al. (2002). Current status of the molecular mechanisms of anticancer drug-induced apoptosis. The contribution of molecular-level analysis to cancer chemotherapy. Cancer Chemother. Pharmacol. 50: 343-352.

Mancebo F, Hilje L, Mora GA and Salazar R (2002). Biological activity of two neem (Azadirachta indica A. Juss., Meliaceae) products on Hypsipyla grandella (Lepidoptera: Pyralidae) larvae. Crop Protect. 21: 107-112.

Mardini H and Record C (2005). Detection assessment and monitoring of hepatic fibrosis: biochemistry or biopsy? Ann. Clin. Biochem. 42: 441-447.

Mekhail TM and Markman M (2002). Paclitaxel in cancer therapy. Expert. Opin. Pharmacother. 3: 755-766.

Mongelli E, Pomilio AB, Sanchez JB, Guerra FM, et al. (2002). ent-Kaur-16-en-19-oic acid, a KB cells cytotoxic diterpenoid from Elaeoselinum foetidum. Phytother. Res. 16: 387-388.

Mosmann T (1983). Rapid colorimetric assay for cellular growth and survival: application to proliferation and cytotoxicity assays. J. Immunol. Methods 65: 55-63.

Navarro A, de las Heras B and Villar A (2000). Immunomodulating properties of the diterpene andalusol. Planta Med. 66: 289-291.

Newman DJ and Cragg GM (2012). Natural products as sources of new drugs over the 30 years from 1981 to 2010. J. Nat. Prod. 75: 311-335.

Olsson M and Zhivotovsky B (2011). Caspases and cancer. Cell Death Differ. 18: 1441-1449.

WHO (2008). Cancer. Fact sheet No. 297.

Patel S and Goyal A (2012). Recent developments in mushrooms as anti-cancer therapeutics: a review. 3 Biotech 2: 1-15.

Paula de Oliveira A, Santin JR, Lemos M, Klein Junior LC, et al. (2011). Gastroprotective activity of methanol extract and marrubiin obtained from leaves of Marrubium vulgare L. (Lamiaceae). J. Pharm. Pharmacol. 63: 1230-1237.

Premprasert C, Tewtrakul S, Plubrukarn A and Wungsintaweekul J (2012). Anti-inflammatory activity of diterpenes from Croton stellatopilosus on LPS-induced RAW264.7 cells. J. Nat. Med. 67: 174-181.

Ribble D, Goldstein NB, Norris DA and Shellman YG (2005). A simple technique for quantifying apoptosis in 96-well plates. BMC Biotechnol. 5: 12.

Roberti A, La Sala D and Cinti C (2006). Multiple genetic and epigenetic interacting mechanisms contribute to clonally selection of drug-resistant tumors: current views and new therapeutic prospective. J. Cell Physiol. 207: 571-581.

Rowinsky EK (1997). The development and clinical utility of the taxane class of antimicrotubule chemotherapy agents. Anпu. Rev. Med. 48: 353-374.

Salatino A, Salatino MLF and Negri G (2007). Traditional uses, chemistry and pharmacology of Croton species (Euphorbiaceae). J. Braz. Chem. Soc. 18: 11-33.

Sun L, Simmerling C and Ojima I (2009). Recent advances in the study of the bioactive conformation of taxol. Chem. Med. Chem. 4: 719-731.

Szakacs G, Paterson JK, Ludwig JA, Booth-Genthe C, et al. (2006). Targeting multidrug resistance in cancer. Nat. Rev. Drug Discov. 5: 219-234.

Vidal V, Potterat O, Louvel S, Hamy F, et al. (2012). Library-based discovery and characterization of daphnane diterpenes as potent and selective HIV inhibitors in Daphne gnidium. J. Nat. Prod. 75: 414-419.t Prod 75: 414-419. 